\title{
Ambidextrous Leadership and Innovative Work Behavior: Mediating Role of Emotional Intelligence
}

\author{
Maryam Hafeez, Siti Aisyah Panatik, Azra Ayue Abdul Rahman, Azizah Rajab, Suaibah Abu \\ Bakar' Irmawati Norazman
}

\begin{abstract}
The purpose of this paper is to study the mediating role of emotional intelligence on the relationship between ambidextrous leadership and innovative work behavior. A total of 130 participants from IT industry of Pakistan filled out the questionnaire. Results revealed that emotional intelligence mediated the relationship between ambidextrous leadership and IWB. The research established that ambidextrous leadership positively influences IWB which includes idea generation as well as idea implementation. Suggestions for future research and practical implications are derived from the results, such as that opening and closing leadership behaviors should be trained to foster IWB.
\end{abstract}

Keywords: Ambidextrous leadership, Emotional intelligence Innovative Work Behavior.

\section{INTRODUCTION}

In todays, increasing globalization and competitiveness between organizations, representatives are tested to leave routine ways and improve their work process or develop innovative products through creative and experimental thinking [1]. For organizations to be able to adapt quickly, innovations are required. [10] characterized innovations as new and valuable thoughts, procedures and items which are created and actualized purposefully in an association. These ideas, processes and products are the result of individual actions of employees and social interactions between employees [7]. Therefore, research should not only concentrate on innovations as a product, but on activities employees carry out that lead to innovations. These activities are called innovative work behavior (IWB) [22].

The question arises how IWB can be fostered. Some studies on innovation at the organizational level focused on leadership as facilitator e.g. [15,11]. However, there is little evidence on the existence of a relationship between leadership and IWB [24]. The results of all these researches

\footnotetext{
Revised Manuscript Received on September 22, 2019.

Maryam Hafeez: PhD Scholar, Azman Hashim Internaltional Business School, Universiti Teknologi Malaysia (UTM), Johor, Malaysia

Assoc. Prof. Dr. Siti Aisyah Panatik: Dr. Azra Ayue Abdul Rahman, Suiabah Abu Bakar; Dr. Irmawati Norazman; School of Human Resource and Phycology, Universiti Teknologi Malaysia (UTM), Johor, Malaysia

Assoc. Prof. Dr. Azizah Rajab; Language Academy, Universiti Teknologi Malaysia (UTM), Johor, Malaysia
}

proposes leadership as the major predictor of innovative behavior.

Though, till today it's not clear to mentioned that which leadership behavior is the superlative predictor of Innovative work behavior [31]. The multiplicity in the past researches on innovative behavior nad leadership leads to the result that, further detailed study is needed in the theory of leadership and innovative behavior [31]. Ambidexterity theory is the new leadership that's is recently getting increasing attention in research. The ambidexterity leadership theory proposed that the collaboration among paired leadership behaviors that is opening and closing foresees innovation individuals and teams, when both opening and closing behaviors of leadership are high which makes the innovation highest [25]. However, those leaders should be successful in boosting innovation between followers who have the ability to involve in both opening and closing behaviors. The second empirical gap that is addressed in this paper is the mediation of emotional intelligence. EI defined as the ability to use their own and others people emotions for developing the liaison with others $[27,19]$. In organization work place behaviors EI has set to be the considerable potential predictor [13]. There are numerous studies that shows the linkage between leadership and emotional intelligence e.g. [2,21] and emotional intelligence and IWB [e.g. 9] but Emotional intelligence as a mediator is not been studied yet specifically between ambidextrous leadership and IWB. This study aims to empirically test the direct and indirect relationship between ambidextrous leadership and innovative work behavior with the mediation of emotional intelligence.

\section{LITERATURE REVIEW}

\section{A. Innovative Work Behaviour:}

IWB is acknowledgment of issues and inception and deliberate presentation of new and helpful thoughts, just as set of practices expected to create, dispatch and execute thoughts with an intend to upgrade individual or potentially business execution $[9,13]$. IWB varies from worker innovativeness which 
focusses on the disclosure and implementation of thoughts [17]. [8] depicted imagination as the way toward starting novel, new and valuable thoughts, while IWB includes set of exercises went for acknowledgment, advancement, alteration, appropriation and usage of thoughts [14,25]. In contrast to inventiveness, IWB has a clearer connected part and is relied upon to create some sort of innovative yield and advantage. In any case, creativity is the base of innovative work behavior, that leads to the overall process of IWB $[3,29]$. IWB has likewise been discovered more extensive than pro activeness develops, for example, proactive work conduct [32] and individual activity [8], which spotlight on person's tendency to actualize thoughts proactively, however can't catch idea generation some portion of innovation process.

\section{B. Ambidextrous Leadership}

Ambidextrous is defined as the ability to use both of hands with same affluence. Balance of exploration and explorative of organization strategies has been linked as ambidextrous, which is the ability to equally well engage in exploration and exploitation [5,12]. As two forms of organization learning exploration and exploitation were the first that introduced [20]. The concept of exploration is clarifying as a raising changes in performance, experimentation engaging, taking risks, and finding for different solutions. On the other hands Exploitation indulge in minimizing changes in behaviors, following the rules, and to avoid the risks [20]. Therefore, ambidextrous leadership is defined as "“'the ability to foster both explorative and exploitative behaviors in followers by increasing or reducing variance in their behavior and flexibly switching between those behaviors" [25].

Opening leadership conduct fundamentally intends to give representatives more opportunity in the achievement of unambiguous tasks [25]. A leader participating in opening leadership conduct urges representatives to not do things like they have constantly done, however break out of these structures and get things done in another manner. The leader's impulse workers to trial and find better approaches for getting things done. Closing leadership conduct intends to confine approaches to achieve explicit assignments [25]. 'closing' suggests that the leaders takes activities that reduce change, intercedes, sets schedules and principles and screens objectives. closing leadership just permits to get things done with a particular goal in mind under the supervision of a manager.

\section{Ambidextrous Leadership and Innovative Work Behaviour}

Ambidextrous leadership theory was created with as premise the presumption that every single inventive activity requires a type of exploration and exploitation exercises [25]. Every one of the four parts of IWB (opportunity exploration, thought age, thought advancement and thought acknowledgment) contain explorative and exploitative exercises which can be cultivated by two correlative administration practices, in light of the fact that the two in blend can fortify innovative and implementation tasks [6].Opening leadership conduct urges to do things another way, consequently reinforcing chance exploration and idea generation, as these expect workers to perceive conceivable outcomes and consider new procedures or items [22]. While closing leadership conduct implies that the leaders defines objectives and screens them, accordingly reinforcing thought advancement and acknowledgment, as these exercises reinforce procedure behaviors [8]. Furthermore, opening leadership conduct likewise supports idea advancement and acknowledgment, in light of the fact that experimental discoveries demonstrate that offering independence to employees does fortify idea generation as well as execution conduct [8]. At last, closing initiative conduct would encourage opportunity exploration and idea generation as there is proof that manager backing and checking activities are emphatically identified with imagination and idea generation $[28,8,32]$. In this way, in light of the theory of ambidextrous leadership it might be normal that opening and closing practices encourage IWB. Besides, of IWB can be reinforced by leaders who show both leadership practices.

$\mathrm{H}_{1}$ : Ambidextrous leadership has significant impact on innovative work behavior

\section{Mediating Role of Emotional Intelligence:}

Emotions is the central conception of cognitive psychology, which is related to the experience of and individual to the objective things. Emotions are affected by external outside the environment as well as the behavioral tendencies of an individual. Emotional intelligence can be used to solve problems and to control behavior, it is the ability to classify and understand yourself and others emotions [27]. [23] contend that emotional intelligence empowers pioneers to comprehend and channel the feelings of subordinates associated with the development procedure. A leader with high emotional intelligence may most likely have an instinct for what sort of conduct their subordinates need to appear and have the option to adjust their leader conduct suitably [33]. Leadership has been shown to be connected to the emotional intelligence. As compared to the average managers, managers who performs well have more self-awareness [4], and emotional intelligence is significantly associated with effectiveness of leaders [16], satisfaction of followers and behavior with extra role [30]. The ambidextrous leadership stated that leaders with opening and closing behaviors are corresponding with the desires of 
innovation as in an individual employees or teams they nurture behavior of exploration and exploitation [25]. Previous studies highlighted that individuals with high EI have good at feelings thoughtful and manage them, which results to lead better outcomes [18] like innovation and leadership. Thus it is hypothesis that:

$\mathrm{H}_{2}$ : Emotional intelligence mediates between Ambidextrous leadership and innovative work behavior.

E.Conceptual Framework.

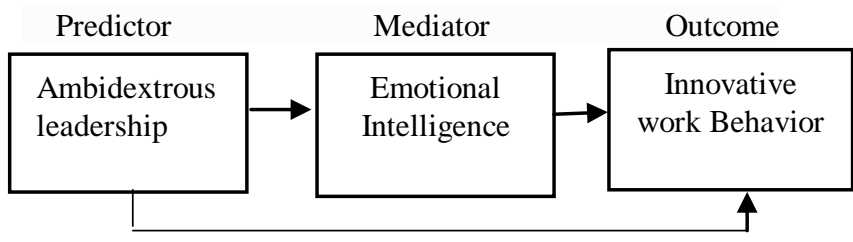

\section{METHODOLOGY}

\section{A. Sample and Procedure}

To explore IWB, information must be gathered in settings where advancements are created and energized. The review study was directed in IT company in Pakistan, at the time when a new application development was in process and that involved work innovation. 40 directors were asked by E-mail to welcome their subordinates to take an interest. Out of 40 chiefs 14 demonstrated enthusiasm for the investigation and got the surveys for their subordinates. Altogether 400 polls were circulated and $\mathrm{N}=130$ participants addressed the survey.

\section{B. Variable Instruments}

IWB was estimated with an approved scale of Messmann \& Mulder [22]. The members were approached to evaluate how regularly they occupied with the 30 behaviors portrayed in the things in the previous a half year on a 5-point Likert scale ( $1=$ never to 5 =always).Ambidextrous leadership was estimated utilizing the opening behavior conduct (test thing: allow various methods for achieving an undertaking; $\alpha=.90$ ) and closing behavior conduct (test thing: Monitor and control objective achievement; $\alpha=.89$ ) scales created in the meta-investigation by Rosing, Frese and Bausch [25] utilizing a 5-point Likert scale from $1=$ never to 5=frequently, quite often. Wong and Law [30] scale is used for measuring emotional intelligence this scale is a 5 point Likert scale from $1=$ never to $5=$ always.

\section{ANALYSIS AND RESULTS}

\section{A. Descriptive Statistics:}

Table 1: Mean, standard deviation, and correlation

\begin{tabular}{lcclll} 
Variables & Mean & $\boldsymbol{S D}$ & $\boldsymbol{A B L}$ & $\boldsymbol{E I}$ & $\boldsymbol{I W B}$ \\
& & & & & \\
\hline ABL & 3.322 & 0.805 & 1 & & \\
EI & 3.469 & 0.619 & $0.279^{* *}$ & 1 & \\
IWB & 3.657 & 0.585 & $0.381^{* *}$ & $0.371^{* *}$ & 1
\end{tabular}

Note: $* *$ Correlation is significant at the 0.01 level (2-tailed). ABL (Ambidextrous Leadership), EI (Emotional Leadership), IWB (Innovative work behavior)

Table 1 displays the variables Mean, standard Deviation and Correlation. Ambidextrous leadership is confidently correlated with IWB $(r=0.381, P<0.01)$ and emotional intelligence $(r=0.279, P$ value $<0.01)$. Furthermore, EI has a significant correlation with IWB $(r=0.371, P<0.01)$. these findings support the hypotheses.

\section{B. Regression Analysis Technique}

Table 2. The regression results and mediation.

\begin{tabular}{lccccc} 
Variables & $\boldsymbol{B}$ & $\boldsymbol{t}$ & $\boldsymbol{p}$ & $\boldsymbol{F}$ & $\boldsymbol{R}^{2}$ \\
& & & & & \\
\hline ABL-IWB & 0.208 & 12.711 & 0.002 & 10.291 & 0.740 \\
EI-IWB & 0.390 & 6.433 & 0.000 & 20.66 & 0.137 \\
ABL-EI-IWB & 0.070 & 5.15 & 0.000 & 26.59 & 0.172 \\
ABL-EI & 0.216 & 3.293 & 0.001 & 10.84 & 0.780
\end{tabular}

Note: ABL (Ambidextrous leadership), EI (Emotional Intelligence), IWB (Innovative work behavior)

Multiple linear regression in SPSS version 23 is used to analysis major hypotheses of the study. In Table 2, the results show the significant effect of predictor on outcome variable that is ambidextrous leadership has a positive effect with IWB ( $\beta=0.208 ; p=0.002$ ), result shows that hypothesis 1 is accepted. $\mathrm{R}^{2}$ value is 0.740 which means variation in IWB is $74 \%$ due to ambidextrous leadership. Therefore, ambidextrous leadership have a significant correlation with $\mathrm{EI}(\beta=0.216 ; p$ $=0.001)$. EI has a significant relationship with IWB $(\beta$ $=0.390, \mathrm{P}=0.000)$. The $\mathrm{R}^{2}$ value signifies a $13 \%$ variation in the IWB. the regression model is significant it supports the hypothesis.

\section{Mediation Effect:}

In table 2 results shows a positive mediation effect of EI among ambidextrous leadership and IWB $(\beta=0.070, \mathrm{P}=$ 0.000 ). therefore, the second hypothesis is completely supported by the outcomes. 


\section{DISCUSSION AND CONCLUSION}

IWB is required to improve developments in associations in the midst of globalization and expanding intensity (Anderson, De Dreu and Nijstad 2004). As a result of the recognized holes in research the point of this investigation was to increase new experiences into the connection between ambidextrous leadership and IWB. Results demonstrated that there is a beneficial outcome of both ambidextrous leaderships on IWB. Moreover, there is a noteworthy cooperation impact of opening initiative conduct and closing authority conduct, which implies that leaders who show both opening and closing administration conduct encourage IWB. Accordingly, this examination gives discoveries that help the ambidextrous leadership theory. Opening and closing authority conduct are correlative administration practices that help IWB [25]. In spite of the fact that the connection among opening and closing authority conduct and IWB is noteworthy, discoveries demonstrate that there are different indicators that can be utilized as extra clarifications for IWB: high inherent inspiration appears to prompt IWB. This goes for opening just as closing initiative conduct. Past examinations have effectively discovered connections between inherent assignment inspiration and employee development.

Despite the fact that the various leveled relapse examination uncovered that inborn assignment inspiration has the most elevated huge association with IWB, leadership continues having an impact. Along these lines it tends to be contended that ambidextrous leadership and emotional intelligence in blend are great indicators for IWB. Moreover, a main position positively affected IWB. That recommends administrators in the association are likelier to be imaginative, than subordinates. It is vague, in any case, why this wonder occurred and ought to be additionally analyzed. Exact proof is conveyed here that administrators need to demonstrate both opening and closing initiative conduct so as to encourage innovative behaviors [31] and to cultivate every one of the four parts of individual IWB.

\section{FUTURE RECOMMENDATIONS}

The study recommend that leaders need an expansive scope of practices to cultivate IWB in organizations. Both opening and closing initiative conduct should be completed by leaders. These results recommend that leadership practices are required. In any case, how to cultivate a wide scope of practices in leaders requires further observational examinations. Satisfactory trainings must be created by HR directors to explicitly prepare ambidextrous administration. Only then senior's managers will most likely explicitly enroll and bolster leaders in divisions, where IWB is required for the expert improvement of employees and the advancement of the organization. last the examination underscored the significance of emotional intelligence. In future it is suggested different other medications can be used to check the relationship between ambidextrous leadership and innovative work behavior. this study is cross-sectional study future studies can use longitudinal research to further analyses the variations in variables in different times. This research is only conducted in Pakistan further research can conduct this in other Asian countries.

\section{REFERENCES}

1. Anderson, N., De Dreu, C. K., \& Nijstad, B. A. (2004). The routinization of innovation research: A constructively critical review of the state-of-the-science. Journal of organizational Behavior, 25(2), 147-173.

2. Antonakis, J., Ashkanasy, N. M., \& Dasborough, M. T. (2009). Does leadership need emotional intelligence? The leadership quarterly, 20(2), 247-261.

3. Afsar, B., F. Badir, Y., \& Bin Saeed, B. (2014). Transformational leadership and innovative work behavior. Industrial Management \& Data Systems, 114(8), 1270-1300.

4. Bruni, R. A., Laupacis, A., Levinson, W., \& Martin, D. K. (2010). Public views on a wait time management initiative: a matter of communication. BMC health services research, 10(1), 228.

5. Benner, M. J., \& Tushman, M. L. (2003). Exploitation, exploration, and process management: The productivity dilemma revisited. Academy of Management Review, 28(2), 238-256

6. De Vries, H., Bekkers, V., \& Tummers, L. (2016). Innovation in the public sector: A systematic review and future research agenda. Public administration, 94(1), 146-166.

7. De Jong, J. (2006). Individual innovation: the connection between leadership and employees' innovative work behavior (No. R200604). EIM Business and Policy Research

8. De Jong, J. P., \& Den Hartog, D. N. (2008). Innovative work behavior: Measurement and validation. EIM Business and Policy Research, 8(1), $1-27$

9. Dincer, H., Gencer, G., Orhan, N., \& Sahinbas, K. (2011). The significance of emotional intelligence on the innovative work behavior of managers as strategic decision-makers. Procedia-Social and Behavioral Sciences, 24, 909-919.

10. Farr, J. L., \& West, M. A. (Eds.). (1990). Innovation and creativity at work: Psychological and organizational strategies. Wiley

11. Gumusluoglu, L., \& Ilsev, A. (2009). Transformational leadership, creativity, and organizational innovation. Journal of business research, 62(4), 461-473.

12. Gibson, C. B., \& Birkinshaw, J. (2004). The antecedents, consequences, and mediating role of organizational ambidexterity. Academy of Management Journal, 47(2), 209-226

13. Higgs, M., \& Aitken, P. (2003). An exploration of the relationship between emotional intelligence and leadership potential. Journal of Managerial psychology, 18(8), 814-823.

14. Imran, R., Saeed, T., Anis-Ul-Haq, M., \& Fatima, A. (2010) Organizational climate as a predictor of innovative work behavior. African Journal of Business Management, 4(15), 3337-3343.

15. Jung, D. I., Chow, C., \& Wu, A. (2003). The role of transformational leadership in enhancing organizational innovation: Hypotheses and some preliminary findings. The leadership quarterly, 14(4-5), 525-544.

16. Kerr, R., Garvin, J., Heaton, N., \& Boyle, E. (2006). Emotional intelligence and leadership effectiveness. Leadership \& Organization Development Journal, 27(4), 265-279.

17. King, N., \& Anderson, N. (2002). Managing innovation and change: A critical guide for organizations. Cengage Learning EMEA 
18. Karim, J., \& Weisz, R. (2011). Emotional intelligence as a moderator of affectivity/emotional labor and emotional labor/psychological distress relationships. Psychological studies, 56(4), 348.

19. Mayer, J. D., \& Salovey, P. (1993). The intelligence of emotional intelligence.

20. March, J.G. (1991), "Exploration and exploitation in organizational learning”, Organization Science, Vol. 2 No. 1, pp. 71-87.

21. Mathew, M., \& Gupta, K. S. (2015). Transformational leadership: Emotional intelligence. SCMS Journal of Indian Management, 12(2), 75 .

22. Messmann, G., \& Mulder, R. H. (2012). Development of a measurement instrument for innovative work behaviour as a dynamic and context-bound construct.Human Resource Development International, 15(1), 43-59.

23. Palmer, B., Donaldson, C., \& Stough, C. (2002). Emotional intelligence and life satisfaction. Personality and individual differences, 33(7), 1091-1100.

24. Pieterse, A. N., Van Knippenberg, D., Schippers, M., \& Stam, D. (2010). Transformational and transactional leadership and innovative behavior: The moderating role of psychological empowerment. Journal of organizational behavior, 31(4), 609-623

25. Rosing, K., Frese, M., \& Bausch, A. (2011). Explaining the heterogeneity of the leadership-innovation relationship.

26. Ruhnke, M., \& Mulder, R. H. Ambidextrous Leadership and Innovative Work Behavior

27. Salovey, P., \& Mayer, J. D. (1990). Emotional intelligence. Imagination, cognition and personality, 9(3), 185-211.

28. Scott, S. G., \& Bruce, R. A. (1994). Determinants of innovative behaviour: A path model of individual innovation in the work place. Academy of management journal,37(3).

29. Sharifirad, M. S. (2013). Transformational leadership, innovative work behavior, and employee well-being. Global Business Perspectives, 1(3), 198-225.

30. Wong, C. S., \& Law, K. S. (2002). The effects of leader and follower emotional intelligence on performance and attitude: An exploratory study. The leadership quarterly, 13(3), 243-274.

31. Zacher, H., \& Rosing, K. (2015). Ambidextrous leadership and team innovation. Leadership \& Organization Development Journal, 36(1) 54-68.

32. Zacher, H., Robinson, A. J., \& Rosing, K. (2016). Ambidextrous leadership and employees' self-reported innovative performance: The role of exploration and exploitation behaviors. The Journal of Creative Behavior, 50(1), 24-46.

33. Zineldin, M., \& Hytter, A. (2012). Leaders' negative emotions and leadership styles influencing subordinates' well-being. The International Journal of Human Resource Management, 23(4), 748-758.

\section{AUTHORS PROFILE}

Maryam Hafeez: PhD Scholar, Azman Hashim International Business School, UTM, Johor Bahru, Malaysia.

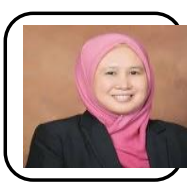

Assoc. Prof. Dr. Siti Aisyah Panatik: Chair of School, School of Human Resource Development \& Psychology, Universiti Teknologi Malaysia (UTM), Johor, Malaysia. Her field of interest in Industrial \& Organizational Psychology (Life Balance, job stress, Work-Related Attitudes, Religiosity and Spirituality at Workplace) \& Psychological Methodology (Psychometric, AMOS). She has published many indexed papers in International Journals.

Dr. Azra Ayue Abdul Rahman , Academic Staff at School of Human Resource Development \& Psychology, Universiti Teknologi Malaysia (UTM), Johor, Malaysia.

Suiabah Abu Bakar, School of Human Resource Development \& Psychology, Universiti Teknologi Malaysia (UTM), Johor, Malaysia.
Associate Professor Dr. Azizah Rajab; Associate Professor at Language Academy, Universiti Teknologi Malaysia (UTM), Johor, Malaysia.

Dr. Irmawati Norazman Academic Staff at School of Human Resource Development \& Psychology, Universiti Teknologi Malaysia (UTM), Johor, Malaysia. 